\title{
Do Low Price Signals Influence Online Purchases of Tourist Accommodation Services? The Moderating Role of Gender
}

\author{
Agustín V. Ruiz Vega ${ }^{1}$, Consuelo Riaño Gil ${ }^{1} \&$ Carla Di Pierri Del Vecchio ${ }^{1}$ \\ ${ }^{1}$ Universidad de La Rioja, Department of Economics and Management, Edificio Quintiliano, c/La Cigüeña 60; \\ 26006 Logroño, Spain \\ Correspondence: Agustín V. Ruiz Vega, Universidad de La Rioja, Department of Economics and Management, \\ Edificio Quintiliano, c/La Cigüeña 60; 26006 Logroño, Spain. Tel: 34-94-129-9392 Fax: 941299393 E-mail: \\ agustin.ruiz@unirioja.es
}

Received: November 10, 2014

Accepted: December 17, $2014 \quad$ Online Published: December 18, 2014

doi:10.5430/bmr.v3n4p96

URL: http://dx.doi.org/10.5430/bmr.v3n4p96

\begin{abstract}
Based on an experimental design applied to online purchases of hotel bookings, this study analyzes the influence of three low price signals and the distribution channel on perceived value and behavioral intentions. Positive influences on perceived value and buying intention were found for price beating guarantee and always low price signals but the distribution channel was only found to have an effect on behavioral intentions. Also, it has been seen that gender plays a moderating role on both perceived value and buying intention. Finally, the most effective low price differ in function of the type of enterprise that is transmitting the information to the consumers: price beating guarantee is the best option for hotel website but always low price guarantee is better for electronic intermediaries.
\end{abstract}

Keywords: Low price guarantee, Low price signal, Price matching guarantee, Price beating guarantee, Tourism

\section{Introduction}

Currently, Internet is experiencing exponential growth as a communication, distribution and sales channel for products and services. In Spain, over the past year, 31\% of all Spaniards made some sort of online purchase; furthermore, the average amount spent rose from $739 €$ per individual in 2008 to $828 €$ in 2012, with tourist services being the most common use of the internet, both to search for information and to make online purchases (Urueña, 2013). This growth in demand contrasts with the reverse evolution of offline retail commerce: the number of travel agencies connected to Amadeus in Spain decreased from 9127 in 2007 to 6075 at the end of last year. This supports our selection of the online purchase of hotel bookings for the application of the theoretical framework described in the following section.

Internet diffusion is leading to changes in how consumers collect information regarding their purchase options, how they analyze this information and how they ultimately make purchases. First, because according to Akerlof, the Internet is a market "for lemons", in which information asymmetry hinders the assessment of purchase options and the price to be paid (Fernández, González \& Prieto, 2010). Second, because hotel chains create multi-channel strategies resulting in paradoxes and contradictions between the options available for tourists in the physical and online environments, increasing consumer price sensitivity (O'Connor, 2002). Third, because consumers attempt to obtain information and signs of quality to assist them in reducing their purchase risk and to help them to make the most efficient purchase decisions (Diehl, Kornish \& Lynch, 2003; Beldona, Morrison \& O’Leary, 2005).

Thus, the increased competition between different distribution channels and within these channels has intensified the use of price as a competitive tool. Specifically, low price signals (always low prices or low price guarantees) have become increasingly popular in both online and offline commerce (Dutta and Bhowmick, 2009). Numerous works have analyzed some of the different low price offers made by sellers: always low prices (ALP) and low price guarantees, which either match their competitor's price- price matching guarantee (PM) or beat the competitor's offer- price beating guarantee (PB) (Alford \& Biswas, 2002; Dutta \& Biswas, 2005; Dutta, Biswas \& Grewal, 2007; Dutta, 2012; Janssen \& Parakhonyak, 2013). However, we are unaware of studies that examine which of these offers are more convenient for consumers and generate better economic results for companies. Therefore, this study aims to offer responses to the following research questions: 
a) Does a significant relationship exist between the low price offers made by sellers on their websites and consumer purchase behavior?

b) Are there differences in the evaluation of these offers when they are made by a hotel or when they are made by electronic intermediaries?

c) Does the gender of the consumer play a moderating role in the proposed relationships?

The remainder of the paper has been organized as follows: Section 2 presents the theoretical framework of the study; for this, there is a successive review of the variables used to define consumer behavior followed by the two causal factors considered in the study and the moderating variable under analysis. In Section 3, the planning and development of the applied experimental design is described. The results obtained from the empirical study are shown in Section 4. Finnally, we offer the principal conclusions and suggestions derived from the study.

\section{Overview of the literatureTheoretical framework}

\subsection{Perceived Offer Value}

The perceived value is defined as the result of the comparison made by the consumer of their perceived benefits and sacrifices (Zeithaml, 1988; McDougall \& Levesque, 2000). This is a subjective concept and a current consensus exists regarding its multi-dimensional nature, given that it seemingly reflects mainly upon consumer purchase behavior, ideally capturing the complexity of the concept and serving as a collective cognitive-affective approximation (Sweeney \& Soutar, 2001).

However, the literature reveals many means of making multi-dimensional measurements of the referred construct, as shown in Figure 1. For this study, the perceived value of the offer construct has been selected. It includes the subjective evaluation made by each potential buyer for each of the purchase alternatives, based on a comparison of their economic cost and their supposed benefits: the greater this difference, the greater the relative position of the determined offer with respect to that of its competitors, thus making it more likely that this product shall be purchased (Alford \& Biswas, 2002; Chen \& Chen, 2010). For measurement purposes, the three-item scale proposed by Alford \& Sherrell (1996) and by Alford \& Biswas (2002) was used, adapted to the study context and hereinafter referred to as POV.

\subsection{Online buying intention}

The construct Online Buying Intention (hereinafter, OBI based on its initials in English) represents the results of the evaluation of the given offer, with respect to the quality of the website, the search and analysis of information, and the evaluation of the product and its characteristics (Hausman and Siekpe, 2009); similarly, this concept offers the best approximation of online purchase behavior (Vijayasarathy, 2004; Lee \& Lin, 2005). Its measurement has been conducted in two different ways: (i) through the use of a direct and unique measurement (Erevelles, Roy \& Yip, 2001; Chen \& Chen, 2010; Dutta, 2012) focusing mainly on short term behavior; and (ii) through a multi-item scale; in this study, we used the scale of three items validated by the literature (Jarvenpaa, Tractinsky \& Vitale, 2000; Van der Heijden \& Verhagen, 2003; Dutta, Biswas \& Grewall, 2007).

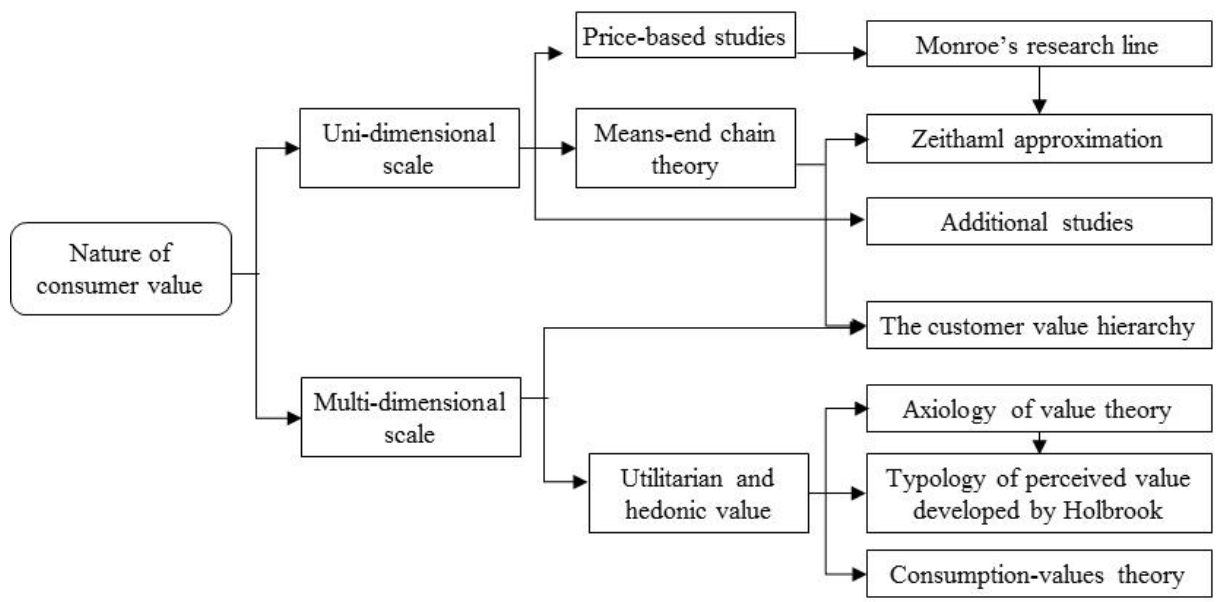

Figure 1. Research streams on perceived value

Source: Sánchez \& Iniesta (2007; 430) 


\subsection{Distribution channel}

The literature regarding the online price effect has traditionally focused on comparisons between online and offline channels; on the one hand, authors such as Brynjolfsson \& Smith (2000) argue that online buyers are more sensitive to price due to the fact that the prices found through Internet searches tend to be lower than those found through the more traditional channels. However, other studies offer contradictory results (such as Chu, Chintagunta \& Cebollada, 2008). In order to understand this apparent discrepancy, the context of each study must be taken into consideration: in the first group of studies, consumers had to select the online and offline establishment where they would make the purchase while in the second group, the job of the purchasers was to fill a shopping cart with products from a store, be it online or offline.

Focusing exclusively on the analysis of the online distribution channels, a greater number of quantitative studies, particularly those applied to the tourist industry, have been directed at: (i) quantifying the price elasticity of consumers making online purchases in different agents (Chevalier \& Goolsbee, 2003); (ii) determining the predisposition to pay for a product in an online environment (Garrow, Jones \& Parker, 2007), as well as whether or not the website's informative content affects the predisposition to pay (Diehl, Kornish \& Lynch, 2003; Miao \& Mattila, 2007); (iii) segmenting the market to understand the weight of the clients who are more sensitive to price, who have a lower per capita cost but more intensely evaluate their purchase experiences and the use of tourist services (Petrick, 2005); (iv) analyzing the influence of online evaluations- e.g. scores provided by tourists in the websites of the hotels and intermediaries, stars given by travellers, etc.- on the perceived value of each hotel offer and on future buying intention (Vermeulen \& Seegers, 2009; Ogut \& Taj, 2012; Sparks, Perkins \& Buckley, 2013). Based on the cited literature, the following hypotheses have been created:

H1: The type of distribution channel used to make the purchase directly influences the perceived value of the offer included in the website.

$\mathrm{H} 2$ : The type of distribution channel used to make the purchase directly influences the online buying intention for the product being sold through the website.

\subsection{Low price signalling}

Quality signals sent to the market by companies, defined as actions used by sellers to transmit credible information to buyers regarding the non-observable quality of the products, are an efficient form of resolving problems of information asymmetry in tourist markets (Spence, 1974; Kirmani \& Rao, 2000; Mavlanova, Benbunan-Fich \& Koufaris, 2012).

Price is simultaneously an indicator of product quality level (signal) and perceived sacrifice resulting from its acquisition; therefore it affects the perceived value of the product and the consumer's willingness to purchase it (Grewal, Monroe \& Krishnan, 1998). Applying the theory of signals to highly competitive markets, for non-frequently purchased products and those having major information asymmetry- as is the case with the purchase of hotel bookings- many companies distribute their products by positioning them as competitive based on price, therefore utilizing two types of low price signals:

(a) Always low prices (ALP) inform consumers that the distribution policy has the objective of offering continuously low prices. It is characterized by a voluntary commitment on behalf of the seller, who is not responsible for compensating the purchaser and by compliance with a purely informative function (Ho, Ganesan \& Oppewal, 2011). In the classification proposed by Kirmani \& Rao (2000), this is a signal that does not relate to failure and that is dependent upon sales since it occurs upon making the purchase, with the purchaser supposedly receiving the benefit associated with the offer.

(b) Low price guarantees (LPG) are those in which the seller agrees to mandatory monetary compensation based on the established price with respect to those of the competition (Mann \& Wissink, 1988). In this case, two types of guarantees exist: (i) matching any competitors' price- price matching guarantee (PM)- where the seller pays the difference between his sales price and that of a competitor, assuming that it has been verified by the purchaser; (ii) beat any competitor's price-price beating guarantee (PB)- where the seller not only pays the difference but offers an additional bonus to purchasers who find a lower price (Dutta, Biswas \& Grewal, 2007). This signal implies an obligatory commitment by the seller and suggests that there shall always be compensation for the purchaser; furthermore, it complies not only with the previously mentioned informative function but also with the protective function for the buyer in the case in she finds a lower price. According to Kirmani \& Rao (2000) it is a dissipative signal given that it implies a risk for sellers in regards to future costs. 
Low price guarantee signals create increased credibility amongst consumers in that the perception of a false offer shall have an economic cost for the company making it and therefore, shall have a greater influence on the perceived value of the consumer and future buying intentions (Erevelles, Roy \& Yip, 2001; Biswas et al., 2002; Dutta \& Biswas, 2005; Lurie \& Srivastava, 2005; Dutta \& Bhomwich, 2009; Hardesty et al., 2012; Janssen \& Parakhonyak, 2013). Thus, when the selling companies are faced with the choice of not making any sort of offer regarding low prices or, in the case that they do, selecting the most appropriate, the following hypotheses have been created:

H3: The presence of an offer of low prices in a specific website directly influences the perceived value of the offer appearing in the website.

H4: The presence of an offer of low prices directly influences the online buying intention via the website.

\subsection{The moderating role of gender}

Various studies have suggested that differences exist in the consumer behavior of men and women in regards to two aspects: the processing of acquired information (Holbrook, 1986; Palmer \& Bejou, 1995) and their responses to the commercial stimulus received (Meyers-Levy, 1989). In regards to information processing, it has been established that women respond to non-verbal stimuli having more associative interpretations and those related to the imagination, and that they value more elaborate descriptions as compared to men (Gilligan, 1982). Thus, it has been suggested that women are more sensitive than men to visual online information when they evaluate products, directly impacting their degree of satisfaction with the website (Gattiker, Perlusz \& Bohmann, 2000; Luo et al., 2006).

Regarding purchase behavior, based on the commercial stimuli received, men tend to develop idiosyncratic behavior with their online purchasing, translating into a greater assertiveness and a higher level of pragmatism as well as a special preference for the rapidness of the online purchase transactions (Chiu, Lin \& Tang, 2005). Therefore, it is relevant to analyze the effects of the type of distribution channel and the price signal used in the channel, based on the gender of the online consumer.

H5a: The gender of the individual shall moderate the influence of the type of distribution channel and the low price signal issued on the perceived offer value.

$\mathrm{H} 5 \mathrm{~b}$ : The gender of the individual shall moderate the influence of the type of distribution channel and the low price signal issued on online buying intention.

Figure 2 summarizes the overall causal model proposed for this study.

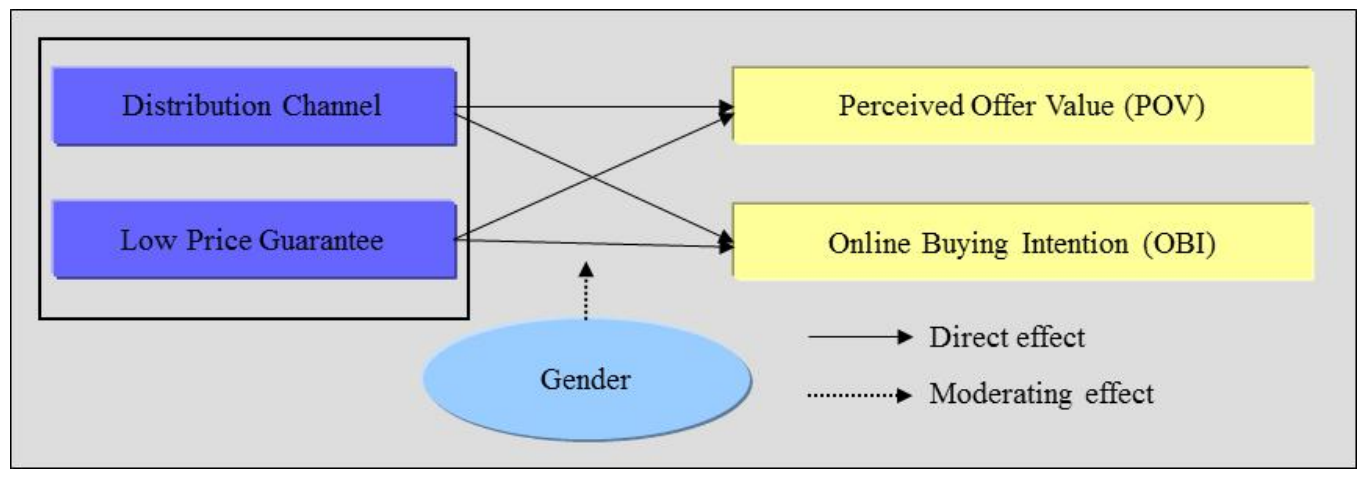

Figure 2. Research proposal

\section{Experimental Design}

This experiment utilized a between-subjects factorial design 2 (distribution channel: direct sale through the hotel chain/sale through an electronic intermediary) x 4 (price signal issued by the seller: none/always low price/matching competitor's price/beating competitor's price). The factorial design is complete (with subjects randomly assigned to all experimental conditions) and balanced (with the same number of subjects assigned to each experimental condition), having the advantage that the sum of the squares for the different effects- main effects and interactionsare correlated, that is, they are orthogonal (Keppel, 2004; Huberty \& Olejnik, 2006).

Study participants were university students. Specialized literature tends to use this group in studies similar to this one (for example, Liang \& Lai, 2002; Lee \& Benbasat, 2003; Jahng, Jain \& Ramamurthy, 2007) for various reasons, five of which are linked to the analyzed market and two of which relate to experimental design: (i) the composition 
of the sample by ages ranging between 18 and 30 allows the study to examine the group of Spanish consumers who make the greatest amount of Internet purchases (Urueña, 2013); (ii) their familiarity with the acquisition of the product that is the subject of this study strengthens the validity of this experiment (Lynch, 1982; Calder, Phillips \& Tybout, 1982); (iii) university students differ from the general population on their intensive and regular use of the Internet, making them considerably more expert online purchasers as compared to the general public (Kirkbride \& Soopramanien, 2010); (iv) they are especially active individuals in regards to the Internet, filtering and disseminating information, opinions and beliefs regarding the content and websites, developing a very significant role as online experts (Shih, 2006; Larsen, Urry \& Axhausen, 2007); (v) this group has a greater probability of becoming online purchasers as compared to other consumers (Park, Lennon \& Stoel, 2005); (vi) maintaining the homogeneity of the subjects, a necessary aspect in order to contrast theories based on the experimental design (Lynch, 1982; Sternthal, Tybout \& Calder, 1994); although the use of young students restricts extrapolation of the results to other populations, it is considered ideal for validating theories (Chang \& Wildt, 1996); and (vii) the need for the subjects to be situated in a computerized classroom in order to view the fictitious internet offers and respond to the different questions makes this an ideal group based on accessibility and operability.

Subject assignment to the analyzed scenarios was carried out randomly, assigning each participant to one of the eight potential combinations of the manipulated variables. Of the 300 surveys received, 288 were valid; therefore 36 individuals were assigned to each cell.

The analyzed stimuli were designed to replicate (in form and size) those that are currently found in the economic tourism websites (see Annexes 1 and 2). The representation of the distribution channel was dichotomized in order to "maximize the difference" between a direct channel in which the actual hotel chain distributes the tourism service and the use of an electronic intermediary (Lee \& Benbasat, 2003); in addition, very well-known brands and leaders of the tourism sector were used in order to prevent a lack of brand credibility influencing the requested opinions and decisions (Erdem, Swait \& Louvière, 2002): the hotel chain Sol-Meliá and the electronic intermediary Booking. Regarding price signals, the guaranteed price seal was used for measuring the level of always low prices, the return of the difference between the amount paid and any competitor's offer was used to define the alternative of matching competitor's offers and the option of improving the price of any competitor was defined as paying five times the difference of the price between that offered by the company and that of any competitor, if this price was found to be lower. In order to most closely emulate the hotel company websites, no previous oral explanation was given to the subjects and both the size and colors of the commercial stimuli of the actual webpages was used in order to give the greatest possible appearance of genuineness to the experiment.

As for the experimental procedures, the study was conducted in a computer classroom with the participants having no knowledge of the real study objective, since it was described as being an analysis of perceptions and behaviors of online purchasers of overnight hotel bookings. In the instructions given, the following situation was presented: purchase decision for a short term vacation trip (3 nights) for two to a sun and beachside destination (Puerto de la Cruz) to be made over Easter Week; for this, participants were to evaluate a specific purchase option, opening a unique and fictitious website prepared so that the dependent variables were manipulated based on the scenario at hand.

In order to isolate the influence of the previously indicated stimuli, different control variables were defined: (a) the selected distribution channel: exclusively electronic commerce; (b) the level of information of the website was identical for the eight scenarios; (c) the presentation of the information was also homogenous; (d) presence of the quality certification $Q$ issued by the ICTE as an additional offer guarantee mechanism; (e) price per overnight booking of $65 €$ per lodging per night in double hotel room, also presented as $32.50 €$ per person, per night to guarantee a homogenous perception of the same by the surveyed (Note 1).

The questionnaire was created on an Excel form, permitting each individual to respond to the questions immediately after having been subjected to the analyzed stimuli. All questions were presented via Likert scales from 0 to 10 points, allowing for the surveyed individuals to precisely express their opinions.

\section{Empirical Results}

In order to check the validity of the scales used to measure the constructs defined in the theoretical framework, a reliability and dimensionality analysis was carried out. First, the reliability of the scales was analyzed, based on Cronbach's alpha coefficient and considering a minimum value of 0.7 (Cronbach, 1970; Nunnally, 1978) and for the item-total correlation between the elements of each dependent variable analyzed, using 0.3 as the minimum value (Bagozzi, 1981; Nurosis, 1993). Second, the one dimensional nature of the scales was examined through factorial analysis of the principal components, considering the unit as the value criteria and verifying that that the factorial 
loads were greater than 0.5 (Hair et al., 1998). In all cases, the results obtained were clearly satisfactory. These results are not detailed here due to space limitations.

In order to verify potential compliance with the defined hypotheses, a two stage analysis was conducted. First, a MANOVA was carried out, including all of the dependent and independent variables proposed. Second, in order to examine the role of consumer gender on all of these relations, a MANCOVA analysis was conducted, using gender as the covariate (Lattin, Carrol \& Green, 2003).

The results obtained in the first stage of the empirical study are presented in Table 1 . When only considering the direct effect of the two causal variables on the two dependent variables, it is found that both POV as well as OBI was affected by the experimental treatments carried out, as shown in the Wilks' lambda distribution. On the one hand, the POV variable was affected by the type of price signal issued in the distribution channel, but at the same time, it was not affected by the economic agent that issued the said signal, either the hotel chain or the electronic intermediary. On the other hand, the dependent OBI variable was affected by both the channel type as well as by the type of price signal issued. Finally, no combined effects were found for the two explanatory variables on any of the dependent variables analyzed. Ultimately, these results led to the rejection of the H1 hypothesis and the acceptance of the other hypotheses: $\mathrm{H} 2, \mathrm{H} 3$ and $\mathrm{H} 4$.

Next, an analysis of the intensity of the variations detected in the two dependent variables, POV and OBI was conducted, based on the experimental treatments to which they were subjected, as shown in Figure 3. With respect to POV, this variable always had higher mean averages when the signal was issued by the hotel chain as opposed to when it was issued by an electronic intermediary, except when no price offers were made, in which case the opposite occurred. Second, the type of price signal issued led to notable differences in POV. When sellers offered always low prices (ALP) or price beating (PB), consumers were more appreciative as opposed to when they offered to match competitors' prices (PM) or when there was no offer made regarding prices (AP). Third, the intensity of the different signals varied in function of the distribution channel. Thus, the ALP offer had the greatest POV value for the electronic intermediaries but when the channel was the hotel chain, PB had the highest value; similarly, the absence of a price-related offer was the least valued POV for the hotels but in the case of the electronic intermediaries, PM had an even lower POV value (a decrease by $11.16 \%$ for the intermediaries as compared to tourism service providers).

Table 1. MANOVAs of the Distribution channel and price signal stimuli on POV and OBI

\begin{tabular}{|c|c|c|c|c|c|c|c|}
\hline & & \multicolumn{3}{|c|}{ POV } & \multicolumn{3}{|c|}{ OBI } \\
\hline $\mathbf{X}_{\mathbf{i}}$ & $\begin{array}{c}\text { Wilks' } \\
\lambda \\
\text { (sign.) }\end{array}$ & $\begin{array}{c}\text { Degrees } \\
\text { of } \\
\text { freedom }\end{array}$ & $\begin{array}{l}\text { Root mean } \\
\text { square }\end{array}$ & F (sign.) & $\begin{array}{l}\text { Degrees } \\
\text { of } \\
\text { freedom }\end{array}$ & $\begin{array}{c}\text { Root mean } \\
\text { square }\end{array}$ & F (sign.) \\
\hline $\begin{array}{c}\text { Distribution } \\
\text { channel }\end{array}$ & $\begin{array}{l}8.492 \\
(0.000)\end{array}$ & 1 & 6.226 & $\begin{array}{c}1.922 \\
(0.167)\end{array}$ & 1 & 15.748 & $\begin{array}{c}5.343 \\
(0.022)\end{array}$ \\
\hline Price signal & $\begin{array}{l}2.305 \\
(0.032)\end{array}$ & 3 & 13.439 & $\begin{array}{l}4.148 \\
(0.007)\end{array}$ & 3 & 9.673 & $\begin{array}{c}3.282 \\
(0.021)\end{array}$ \\
\hline $\begin{array}{l}\text { Interaction effect } \\
\text { (Channel x Price) }\end{array}$ & $\begin{array}{l}0.799 \\
(0.571)\end{array}$ & 3 & 2.393 & $\begin{array}{l}0.739 \\
(0.530)\end{array}$ & 3 & 1.525 & $\begin{array}{l}0.517 \\
(0.671)\end{array}$ \\
\hline
\end{tabular}



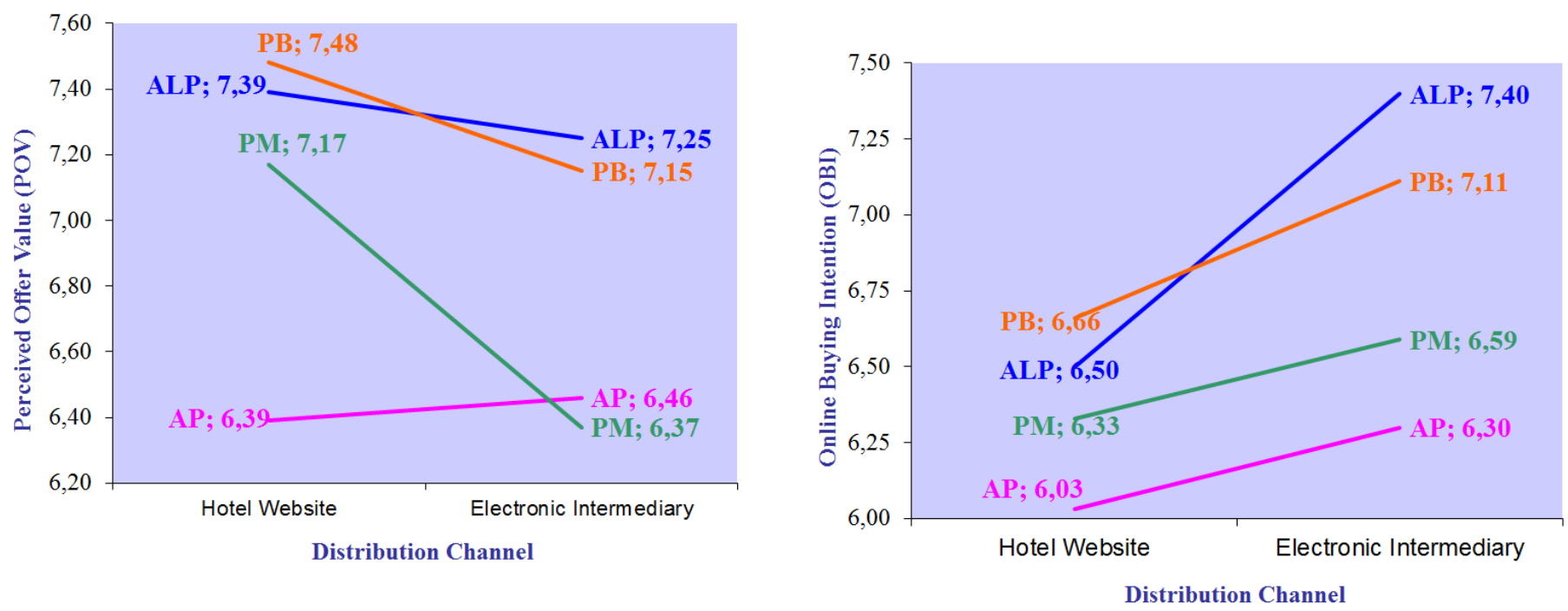

Figure 3. Influence of the distribution channel and price signal stimuli on POV and OBI

As for the OBI variable, electronic intermediaries always had higher values than hotel chains, regardless of the price stimuli to which each subject was subjected. Furthermore, the ranking of the consumer evaluation is quite similar for the two distribution channels; for the hotels, the PB offer generated the greatest online buying intention followed closely by the offer of always low prices (ALP); while price matching (PM) and the absence of any price-related offer (AP) obtained lower values. However, in the case of the electronic intermediaries, ALP resulted in the highest intention to make a future purchase, surpassing the offer to beat out competitors' prices; furthermore, these two offers not only generated greater online buying intention as compared to PM or the absence of any offer, but the OBI difference is greater than that found for the hotel chains.

The second stage of empirical analysis was the incorporation of gender (Note 2) as a moderating variable for the relationship between the dependent variables and the stimuli analyzed, resulting in significant changes in the obtained results, as revealed in Table 2. First, channel type significantly influenced OBI but, as occurred in the previous case, it did not affect POV, leading to the acceptance of $\mathrm{H} 2$ and the rejection of $\mathrm{H} 1$. Likewise, the price signal issued has a significant effect on POV as well as on OBI, leading to the acceptance of the $\mathrm{H} 3$ and $\mathrm{H} 4$ hypotheses. 
Table 2. MANOVAs of the distribution channel and price signal stimuli on POV and OBI based on the moderating effect of gender

\begin{tabular}{|c|c|c|c|c|c|c|c|}
\hline & & \multicolumn{3}{|c|}{ POV } & \multicolumn{3}{|c|}{ OBI } \\
\hline $\mathbf{X}_{\mathbf{i}}$ & $\begin{array}{c}\text { Wilks } \\
\lambda \\
\text { (sign.) }\end{array}$ & $\begin{array}{c}\text { Degrees } \\
\text { of } \\
\text { freedom }\end{array}$ & $\begin{array}{l}\text { Root mean } \\
\text { square }\end{array}$ & F (sign.) & $\begin{array}{c}\text { Degrees } \\
\text { of } \\
\text { freedom }\end{array}$ & $\begin{array}{l}\text { Root mean } \\
\text { square }\end{array}$ & F (sign.) \\
\hline $\begin{array}{c}\text { Distribution } \\
\text { channel }\end{array}$ & $\begin{array}{l}8.014 \\
(0.000)\end{array}$ & 1 & 7.525 & $\begin{array}{l}2.344 \\
(0.127)\end{array}$ & 1 & 13.320 & $\begin{array}{l}4.548 \\
(0.034)\end{array}$ \\
\hline Price signal & $\begin{array}{l}2.224 \\
(0.040)\end{array}$ & 3 & 12.684 & $\begin{array}{c}3.950 \\
(0.009)\end{array}$ & 3 & 9.016 & $\begin{array}{l}3.100 \\
(0.027)\end{array}$ \\
\hline Gender & $\begin{array}{l}4.000 \\
(0.019)\end{array}$ & 1 & 21.284 & $\begin{array}{c}6.629 \\
(0.011)\end{array}$ & 1 & 17.562 & $\begin{array}{l}6.038 \\
(0.015)\end{array}$ \\
\hline $\begin{array}{c}\text { Channel x Price } \\
\text { Signal Effect }\end{array}$ & $\begin{array}{l}0.831 \\
(0.546)\end{array}$ & 3 & 2.379 & $\begin{array}{c}0.741 \\
(0.529)\end{array}$ & 3 & 1.979 & $\begin{array}{l}0.681 \\
(0.565)\end{array}$ \\
\hline $\begin{array}{c}\text { Channel } x \\
\text { Gender Effect }\end{array}$ & $\begin{array}{l}0.393 \\
(0.676)\end{array}$ & 1 & 0.013 & $\begin{array}{c}0.004 \\
(0.950)\end{array}$ & 1 & 1.364 & $\begin{array}{l}0.469 \\
(0.494)\end{array}$ \\
\hline $\begin{array}{l}\text { Price Signal x } \\
\text { Gender Effect }\end{array}$ & $\begin{array}{l}0.859 \\
(0.525)\end{array}$ & 3 & 2.900 & $\begin{array}{c}0.903 \\
(0.440)\end{array}$ & 3 & 4.211 & $\begin{array}{l}1.448 \\
(0.229)\end{array}$ \\
\hline $\begin{array}{c}\text { Channel x Price } \\
\text { Signal x Gender } \\
\text { Effect }\end{array}$ & $\begin{array}{l}0.301 \\
(0.936)\end{array}$ & 3 & 0.826 & $\begin{array}{c}0.257 \\
(0.856)\end{array}$ & 3 & 0.864 & $\begin{array}{l}0.297 \\
(0.828)\end{array}$ \\
\hline
\end{tabular}

With respect to the effects of the analyzed stimuli on the dependent variables, it was found that the gender of the purchaser affects the intensity of the evaluations made regarding POV and OBI. As for POV, regardless of the channel, the most valued offer for men was found to be PB, that is, beating the economic conditions offered by the competitors (see Figure 4); however, the offer of always low prices obtained similar results in the case of electronic intermediaries although slightly higher values were found for the hotel chains. As for the offer of matching the competitors' prices (PM), this was the third most valued offer for the hotel websites but fell dramatically to the last position when the channel was the electronic intermediary; finally, the absence of any price offers is the most poorly valued option for the hotels but is preferred to the PM alternative for the electronic intermediaries.

As for women, it was quite interesting to find that the offer of competitor price matching (PM) was the most highly valued signal when made by the hotel chain, but when using electronic intermediaries, it is the least valued, even below the absence of any price-related offers (AP). Overall, women appeared to prefer the ALP option regardless of the purchase channel, although the PB offer was found to have an equal value in both distribution channels, while the other offers regarding prices had lower values when they were made via the electronic intermediary.

Gender was also found to have a moderating effect on OBI. For men (Figure 5), PB was the most valued option when acquiring the tourist service from the hotel website but when the purchase was made via an electronic intermediary, even though it is more highly valued, the greatest online buying intention is found with the always low 
prices (ALP) offer. It is also noteworthy that the PM option led to a greater OBI when offered by the hotel as opposed to when it was made via an electronic intermediary, a situation in which the absence of price offers, AP, paradoxically had a greater OBI than the PM option.
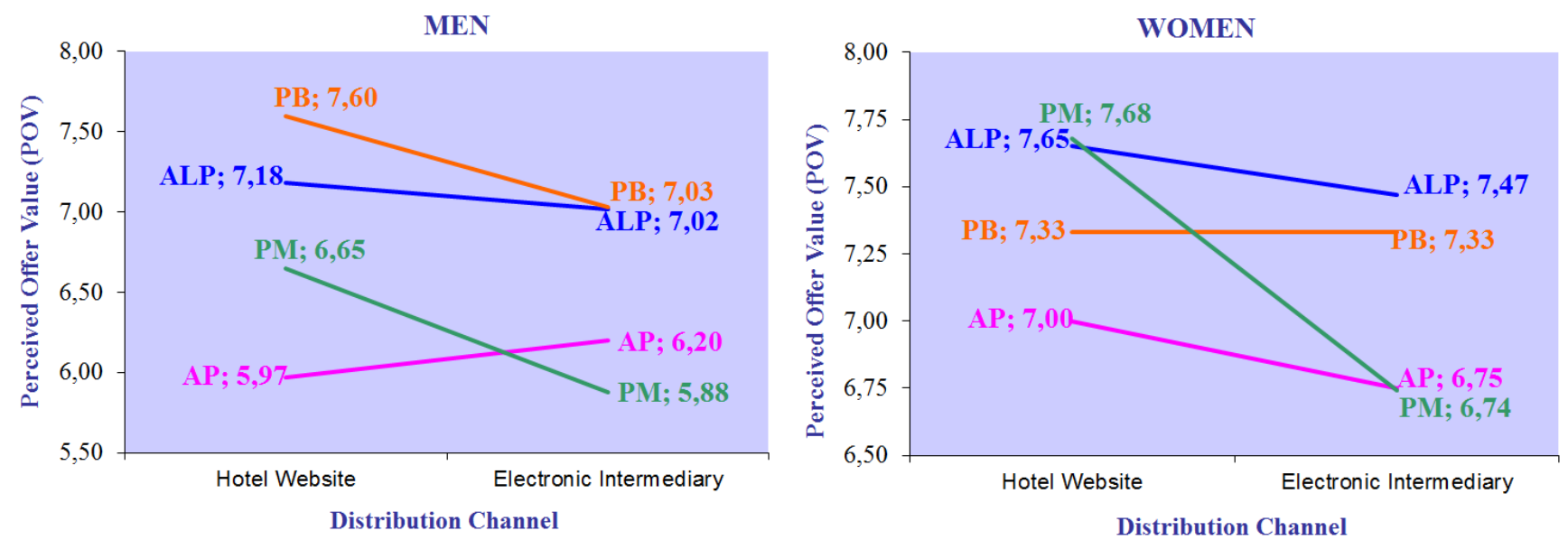

Figure 4. Influence of the channel and price signal stimuli on POV based on gender

The results obtained for OBI for women differed substantially from those found for men. On the one hand, and in reference to the direct hotel distribution channel, the four analyzed options of price offers obtain an almost identical online buying intention, and even the OBI corresponding to the absence of a price offer is only slightly higher than the others. However, in the case of the electronic intermediaries, the situation is quite different since, although the online buying intention always increases, it does so differently based upon the price offer made by the intermediary. When the always low price offer (ALP) is made, a greater OBI is obtained, followed by the offer to beat the competitors' prices and, slightly behind these, the offer to match competitors' prices (PM).
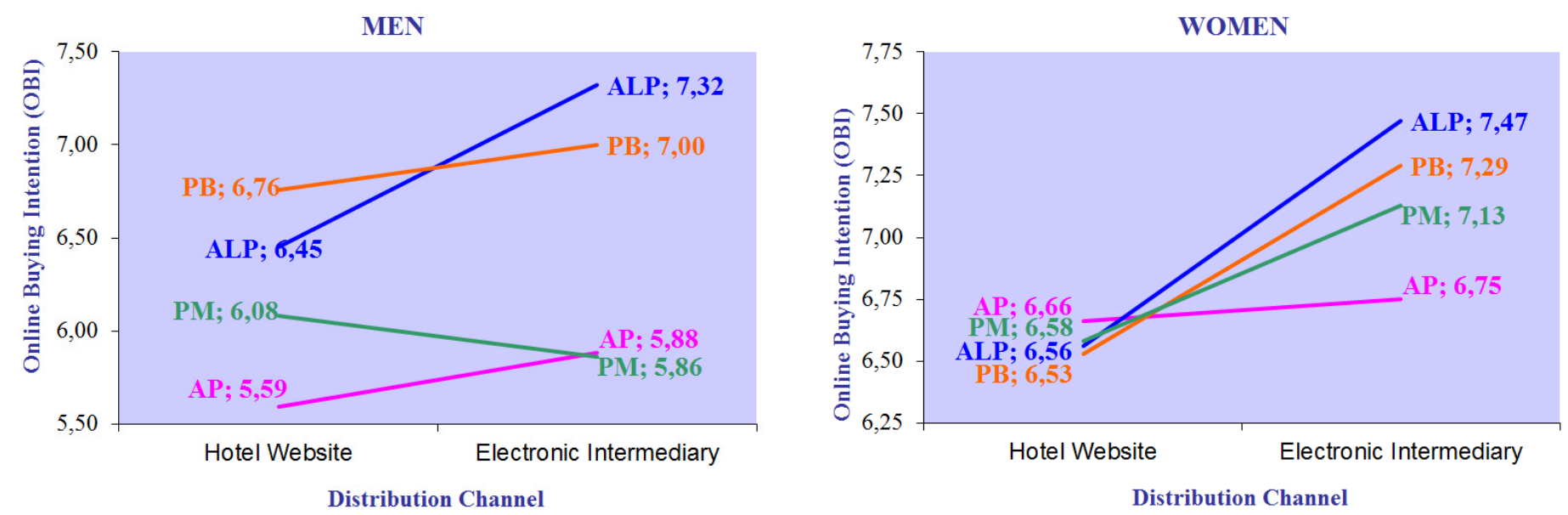

Figure 5. Influence of the channel and price signals stimuli on OBI based on gender

\section{Conclusions, business implications and limitations}

From an academic perspective, the results allow us to conclude that the analyzed individuals do not have different perceptions of the offer value for the two distribution channels: the hotel website and the electronic intermediary website, leading us to reject the H1 hypothesis. However, distribution channel does significantly influence online buying intention, thus the $\mathrm{H} 2$ hypothesis has been accepted. As for the different options related to the explicit price 
offers, statistical differences were revealed for the two dependent variables, leading to the acceptance of the $\mathrm{H} 3$ and $\mathrm{H} 4$ hypotheses and suggesting an increased sensitivity to price by the young consumers in this market.

From a business perspective, the first conclusion that may be drawn from the results is the superiority of the ALP and PB offers, given that they contribute to an improved offer evaluation, an aspect that is relevant to the creation of middle and long term loyalty, as well as to an increased online buying intention. However, it was found that in the case of the hotel websites, the price signal generating the greatest perception of offer value and simultaneously, the greatest intent to make an online purchase is the offer of beating the competitors' price (PB). Similarly, in the case of the electronic intermediaries, the always low price (ALP) offer maximizes both POV and OBI. Finally, the offer of matching the competitors' price (PM) is less valued by users than the two previously cited offers when making purchases from the hotel websites, a difference that is higher in the case of the electronic intermediaries; there are at least two possible explanations for this: the lack of credibility of the issued price signal (PM) when purchasing from the electronic intermediary website, particularly affecting those clients who are more sensitive to price, and/or the fact that purchasers in the electronic intermediary website may have a more transactional mentality, leading them to seek lower prices without the need for delays or additional costs, in terms of effort and personal time, in order to obtain the economic benefit associated with a lower price. In addition, the literature suggests two additional causes: the perceived price dispersion (Biswas, Dutta \& Pullig, 2006) aspect, which was not analyzed in this study, as well as the credibility of the price signal, two potential limitations of this research.

The fact that the matching of competitors' price (PM) offer obtains a greater perceived value and intent to make future purchases than the always lower price (ALP) offer in the case of the hotel chains is in line with our expectations, but this was not the case when this offer was made via electronic intermediaries. This may be due to a lack of credibility in the offer, considering it to be a hidden publicity strategy (Mañez, 2006) or because these purchasers are less expert and may distrust the signal associating it with higher priced products (Dutta, 2012), in which case it would be a vulnerability of the PM signal.

Gender has been found to have a significant effect on the evaluation of the information received from the web and on decision making, leading to the acceptance of the $\mathrm{H} 5$ hypothesis. Women were found to have greater differences in the evaluation of the offer to match competitors' prices (PM), which was highly valued in the context of the hotel chain websites but which is much less important in the case of the electronic intermediaries, and they consistently value the always low prices (ALP) offer. Thus, the results suggests that this group is more sensitive to price and/or that they place less credibility in the signal of matching the competitors' prices than men; this view increases when they visit the websites of the electronic intermediaries, perhaps because, by purchasing directly from the hotel they hope to obtain the lowest possible price on the market. Thus, women, more than men, are found to value the offers of always low prices and beating the competitors' prices when made via an electronic intermediary.

However, literature regarding prices not only links increased price sensitivity to economic gain, thanks to the lower purchase price, but also to social compensation (Urbany, Dickson \& Kalapurakal, 1996; Petrick, 2005), specifically in two aspects: enjoying the purchase process, and discovering offers in order to subsequently share them with friends and family to gain "social profitability" from being viewed as an expert in the market (market maven). Further analysis of this idea may be of interest to future research studies.

The present research has its share of limitations. First, implicit in our proposed mechanism for default effects is the assumption that consumers elaborate information rational and sufficiently, something that is speculative in nature but similar to prior studies (Dutta, Biswas \& Grewal, 2007). Second, consumer value consciousness and price consciousness are important consumer characteristics with respect to price-related perceptions (Lichtenstein, Ridgway \& Netemeyer, 1993); given consumer tendencies to maximize acquisition and transaction values, it is possible that consumers with higher levels of value and price consciousness process price guarantee signals more critically (Biswas, Dutta \& Pullig, 2006). For further studies, the analysis of the potential effect of consciousness process price signals could be an interesting research perspective. Third, the youth of the sample has the advantage the homogeneity of the sample but also has an important limitation: do not allow us analyze the potential influence of different moderating effects that could be linked to the accumulated experience of consumers in relation with a specific product and its consequences about a better information processing (Eisend, 2010); for this reason, could be interesting in the future study the potential influence of different proxy variables of this construct, with demographics (as age or studies) and buying habits (differentiation between heavy users and other types of consumers). 


\section{References}

Alford, B. L.; Biswas, A. (2002). The effects of discount level, price consciousness and sale proneness on consumers' price perception and behavioral intention, Journal of Business research, 55(9), 775-783. http://dx.doi.org/10.1016/S0148-2963(00)00214-9

Alford, B. L.; Sherrell, D. L. (1996). The role of affect in consumer satisfaction judgements of credence-based services, Journal of Business Research, 37, 71-84. http://dx.doi.org/10.1016/0148-2963(96)00030-6

Bagozzi, R. P. (1981). Principles of Marketing Research, Blackwell, Oxford.

Beldona, S.; Morrison, A. M.; O'Leary, J. (2005). Online shopping motivations and pleasure travel products: a $\begin{array}{lllll}\text { correspondence } \quad \text { analysis, } & \text { Tourism } & \text { Management, } & 26 & \text { (4), }\end{array}$ http://dx.doi.org/10.1016/j.tourman.2004.03.008

Biswas, A.; Dutta, S. y Pullig, C. (2006). Low price guarantees as signals of lowest price: The moderating role of perceived price dispersion, Journal of Retailing, 82(3), 245-257. http://dx.doi.org/10.1016/j.jretai.2005.07.007

Biswas, A.; Pullig, C.; Yagci, M. I.; Dean, D. H. (2002). Consumer evaluation of low price guarantees: the moderating role of reference price and store image, Journal of Consumer Psychology, 12(2), 107-118. http://dx.doi.org/10.1207/S15327663JCP1202_04

Brynjolfsson, E.; Smith, M. D. (2000). Frictionless commerce? A comparison of internet and conventional retailers, Management Science, 46, 563-585. http://dx.doi.org/10.1287/mnsc.46.4.563.12061

Calder, B. J., Philips, L. W.; Tybout, A. M. (1982). Designing research for application, Journal of Consumer Research, 8, pp. 197-207. http://dx.doi.org/10.1086/208856

Chang, T. Z.; Wildt, A. R. (1996). Impact of product information on the use of price as a quality cue, Psychology \& Marketing, $13 \quad$ 55-75. http://dx.doi.org/10.1002/(SICI)1520-6793(199601)13:1<55::AID-MAR4>3.0.CO;2-O

Chen, C. F.; Chen, F. S. (2010). Experience quality, perceived value, satisfaction and behavioral intentions for heritage tourists, Tourism Management, 31, 29-35. http://dx.doi.org/10.1016/j.tourman.2009.02.008

Chevalier, J.; Goolsbee, A. (2003). Measuring prices and price competition online: Amazon.com and BarnesandNoble.com, Quantitative Marketing \& Economics, 1 (2), 203-222. http://dx.doi.org/10.1023/A:1024634613982

Chiu, Y.; Lin, C.; Tang, L. (2005). Gender differs: Assessing a model of online purchase intentions in e-rail service, International Journal of Service Industry Management, 16, 416-433. http://dx.doi.org/10.1108/09564230510625741

Chu, J.; Chintagunta, P. K.; Cebollada, J. (2008). Comparison of within-household price sensitivity across online and offline channels, Marketing Science, 27, 283-299. http://dx.doi.org/10.1287/mksc.1070.0288

Cronbach, L. J. (1970). Essentials of psychological testing. Harper and Row, New York.

Diehl, K.; Kornish, L.; Lynch, J. (2003). Smart agents: when lower search costs for quality information increase price sensitivity, Journal of Consumer Research, 30, 56-71. http://dx.doi.org/10.1086/374698

Dong, X.; Zhao, S.; Jiang, X. (2013). An empirical investigación of inertia and shock effects on consumers' choice of online search strategy, Communications in Information Science and Management Engineering, 3 (10), 516-523.

Dutta, S. (2012). Vulnerability to Low-Price Signals: An Experimental Study of the Effectiveness of Genuine and Deceptive Signals, Journal of Retailing, 88 (1), 156-167. http://dx.doi.org/10.1016/j.jretai.2011.08.003

Dutta, S.; Bhowmick, S. (2009). Consumer responses to offline and online low price signals: The role of cognitive elaboration, Journal of Business Research, 62(6), 629-635. http://dx.doi.org/10.1016/j.jbusres.2008.01.042

Dutta, S.; Biswas, A. (2005). Effects of low price guarantees on consumer post-purchase search intention: The moderating roles of value consciousness and penalty level, Journal of Retailing, 81(4), 283-291. http://dx.doi.org/10.1016/j.jretai.2005.08.001

Dutta, S.; Biswas, A.; Grewal, D. (2007). Low price signal default: an empirical investigation of its consequences, Journal of the Academy of Marketing Science, 35(1), 76-88. http://dx.doi.org/10.1007/s11747-007-0017-5 
Eisend, M. (2010). «A meta-analysis of gender roles in advertising», Journal of the Academy of Marketing Science, 38(4), 418-440. http://dx.doi.org/10.1007/s11747-009-0181-x

Erdem, T.; Swait, J.; Louviere, J. (2002). The impact of brand credibility on consumer price sensibility, Journal of Research in Marketing, 19, 1-19. http://dx.doi.org/10.1016/S0167-8116(01)00048-9

Erevelles, S.; Roy, A.; Yip, L. S. C. (2001). The universality of the signal theory for products and services, Journal of Business Research, 52, 175-187. http://dx.doi.org/10.1016/S0148-2963(99)00069-7

Fernández Barcala, M.; González, M.; Prieto, J. (2010). Hotel quality appraisal on the Internet: a market for lemons?, Tourism Economics, 16 (2), 345-360. http://dx.doi.org/10.5367/000000010791305635

Garrow, L. A.; Jones, S. P.; Parker, R. A. (2007). How much airline customers are willing to pay: An analysis of price sensitivity in online distribution channels, Journal of Revenue \& Price Management, 5 (1), 271-290. http://dx.doi.org/10.1057/palgrave.rpm.5160052

Gattiker, U. E.; Perlusz, S.; Bohmann, K. (2000). Using the internet for B2B activities: a review and future directions for research, Internet Research: Electronic Networking Applications and Policy, 10, 126-140. http://dx.doi.org/10.1108/10662240010322911

Gilligan, C. (1982). In a different voice: Psychological theory and women's development. Harvard University Press, Cambridge.

Grewal, D.; Monroe, K. B.; Krishnan, R. (1998). The effects of price-comparison advertising on buyers' perceptions of acquisition value, transaction value, and behavioral intentions, Journal of marketing, 62(2), 46-59. http://dx.doi.org/10.2307/1252160

Hair, J. F.; Anderson, R. E.; Tatham, R. L.; Black, W. C. (1998). Multivariate Data Analysis. Prentice-Hall, Englewood Cliffs.

Hardesty, D. M.; Bearden, W. O.; Haws, K. L.; Kidwell, B. (2012). Enhancing perceptions of price-value associated with price-matching guarantees, Journal of Business Research, 65(8), 1096-1101. http://dx.doi.org/10.1016/j.jbusres.2011.08.024

Hausman A. V.; Siekpe J. S. (2009). The effect of web interface features on consumer online purchase intentions, Journal of Business Research, 62 (1), 5-13. http://dx.doi.org/10.1016/j.jbusres.2008.01.018

Ho, H.D.; Ganesan, S.; Oppewal, H. (2011). The impact of store-price signals on consumer search and store evaluation, Journal of Retailing, 87 (2), 127-141. http://dx.doi.org/10.1016/j.jretai.2011.01.007

Holbrook, M. B. (1986). Aims, concepts and methods for the representation of individual differences in aesthetic response to design features, Journal of Consumer Research, 13, 337-347. http://dx.doi.org/10.1086/209073

Huberty, C. J.; Olejnik, S. (2006). Applied MANOVA and discriminant analysis. Wiley-Interscience, Hobeken, $2^{\mathrm{a}}$ edición.

Jahng, J.; Jain, H.; Ramamurthy, K. (2007). Effects of interaction richness on consumer attitudes and behavioural intentions in e-commerce: Some experimental results. European Journal of Informations Systems, 16, 254-269. http://dx.doi.org/10.1057/palgrave.ejis.3000665

Janssen, M. C.; Parakhonyak, A. (2013). Price matching guarantees and consumer search, International Journal of Industrial Organization, 31(1), 1-11. http://dx.doi.org/10.1016/j.jindorg.2012.10.001

Jarvenpaa, S. L.; Tractinsky, N.; Vitale, M. (2000). Consumer trust in an internet retail service quality, Information Technology and Management, 1 (1), 45-71. http://dx.doi.org/10.1023/A:1019104520776

Keppel, G. (2004). Design and analysis: A researcher's handbook. Prentice-Hall, New Jersey, $4^{\mathrm{a}}$ ed.

Kirkbride, C.; Soopramanien, D. (2010). Competition online and the preference ordering of offers, The International Review of Retail, Distribution and Consumer Research, 20 (4), 379-395. http://dx.doi.org/10.1080/09593969.2010.504005

Kirmani, A.; Rao, A. R. (2000). No pain, no gain: a critical review of the literature on signaling unobservable product quality, Journal of Marketing, 64, 66-79. http://dx.doi.org/10.1509/jmkg.64.2.66.18000

Larsen, J.; Urry, J.; Axhausen, K. W. (2007). Networks and tourism. Mobile social life, Annals of Tourism Research, 34 (1), 244-262. http://dx.doi.org/10.1016/j.annals.2006.08.002

Lattin, J.; Carrol, J. D.; Green, P. E. (2003). Analyzing multivariate data. Thomson, Duxbury. 
Lee, G. G.; LIN, H. F. (2005). Customer perceptions of e-service quality in online shopping, International Journal of Retail \& Distribution Management, 33 (2), 161-176. http://dx.doi.org/10.1108/09590550510581485

Lee, W.; Benbasat, I. (2003). Designing an electronic commerce interface: Attention and product memory as elicited by web design, Electronic Commerce Research and Applications, 2, 240-253. http://dx.doi.org/10.1016/S1567-4223(03)00026-7

Liang, T. P.; Lai H. J. (2002). Effect of store design on consumer purchases: An empirical study of on-line bookstores, Information and Management, 39, 431-444. http://dx.doi.org/10.1016/S0378-7206(01)00129-X

Lichtenstein, D. R.; Ridway, N. M.; Netemeyer, R. G. (1993). Price perceptions and consumer shopping behavior, Journal of Marketing Research, 30 (2), 234-245. http://dx.doi.org/10.2307/3172830

Luo, J. T.; McGoldrick, P.; Beatty, S.; Kathleen, A. K. (2006). On screen characters: their design and influence on consumer trust, Journal of Services Marketing, 20, 112-124. http://dx.doi.org/10.1108/08876040610657048

Lurie, N. H.; Srivastava, J. (2005). Price-matching guarantees and consumer evaluations of price information, Journal of Consumer Psychology, 15(2), 149-158. http://dx.doi.org/10.1207/s15327663jcp1502_7

Lynch, J. G. (1982). On the external validity of experiments in consumer research, Journal of Consumer Research, 9 , 225-239. http://dx.doi.org/10.1086/208919

Mañez, J. A. (2006). Unbeatable Value Low - Price Guarantee: Collusive Mechanism or Advertising Strategy?, $\begin{array}{lllll}\text { Journal of Economics } \& \text { Management } & \text { Strategy, } & 15(1), & 143-166 .\end{array}$ http://dx.doi.org/10.1111/j.1530-9134.2006.00095.x

Mann, D. P.; Wissink, J.P. (1988). Money-back contracts with double moral hazard, RAND Journal of Economics, 19 (2), 285-292. http://dx.doi.org/10.2307/2555706

Mavlanova, T.; Benbunan-Fich, R.; Koufaris, M. (2012). Signaling theory and information asymmetry in online commerce, Information \& Management, 49, 240-247. http://dx.doi.org/10.1016/j.im.2012.05.004

McDougall, G. J.; Levesque, T. (2000). Customer satisfaction with wervices putting perceived value into the equation, International Journal of Research in Marketing, 14 (5), 392-410.

Meyers-Levy, J. (1989). The influence of sex roles on judgement, Journal of Consumer Research, 16 (1), 76-86. http://dx.doi.org/10.1086/209195

Miao, L.; Mattilla, A. S. (2007). How and how much to reveal? The effects of price transparency on consumers' price perceptions, Journal of Hospitality \& Tourism Research, 31 (4), 535-545.

Nunnally, J. C. (1978). Psychometric theory. McGraw-Hill, New York, $2^{\mathrm{a}}$ ed.

Nurosis, M. J. (1993). SPSS. Statistical Data Analysis. SPSS Inc.

O'Connor, P. (2002). An empirical analysis of hotel chain online pricing strategies, Information Technology \& Tourism, 5 (2), 65-72. http://dx.doi.org/10.3727/109830502108751055

Ogut, H.; Taj, B. K. O. (2012). The influence of internet customer reviews on the online sales and prices in hotel industry, The Service Industries Journal, 32 (2), 197-214. http://dx.doi.org/10.1080/02642069.2010.529436

Palmer, A.; Bejou, D. (1995). The effects of the gender on the development of relationships between clients and financial advertisers, International Journal of Bank Marketing, 13 (3), 18-27. http://dx.doi.org/10.1108/02652329510082988

Park, J.; Lennon, S.; Stoel, L. (2005). Online product presentation: Effects on mood, perceived risk, and purchase intention, Psychology and Marketing, 22 (9), 695-719. http://dx.doi.org/10.1002/mar.20080

Petrick, J. F. (2005). Segmenting cruise passengers with price sensitivity, Tourism Management, 26 (5), 753-762. http://dx.doi.org/10.1016/j.tourman.2004.03.015

Sánchez, R.; Iniesta, M. A. (2007). The concept of perceived value: a systematic review of the research, Marketing Theory, 7 (4), 427-451. http://dx.doi.org/10.1177/1470593107083165

Shih, H. Y. (2006). Network characteristics of drive tourism destinations: An application of network analysis in tourism, Tourism Management, 27, 1029-1039. http://dx.doi.org/10.1016/j.tourman.2005.08.002

Sparks, B. A.; Perkings, J. E.; Buckley, R. (2013). Online travel reviews as persuasive communication: The effects of content type, source, and certification logos on consumer behavior, Tourism Management, 39, 1-9. http://dx.doi.org/10.1016/j.tourman.2013.03.007 
Spence, A. M. (1974). Market signaling: Information transfer in hiring and related screening processes. Harvard University Press, Cambridge.

Sterntahl, B.; Tybout, A. M.; Calder, J. B. (1994). Principles of Marketing Research, Blackwell, Cambridge, 195-223.

Sweeney, J. C.; Soutar, G. N. (2001). Consumer perceived value: The development of a multiple item scale, Journal of Retailing, 77, 203-220. http://dx.doi.org/10.1016/S0022-4359(01)00041-0

Urbany, J. E.; Dickson, P. R.; Kalapurakal, R. (1996). Price search in the retail grocery market, Journal of Marketing, 60 (2), 91-104. http://dx.doi.org/10.2307/1251933

Urueña, A. (coord.) (2013). La sociedad en red. Informe anual 2012. Observatorio nacional de las telecomunicaciones y la SI, Madrid.

Van Der Heijden, H.; Verhagen, T. (2003). Online store image: Conceptual foundations and empirical measurement, Informations and Management, 41, 609-617. http://dx.doi.org/10.1016/j.im.2003.07.001

Vermeulen, I. E.; Seegers, D. (2009). Tried and tested: The impact of online hotel reviews on consumer consideration, Tourism Management, 30 (1), 123-127. http://dx.doi.org/10.1016/j.tourman.2008.04.008

Vijayasarathy, L. R. (2004). Predicting consumer intentions to use on-line shopping: the case for an augmented technology acceptance model, Information \& Management, 41 (6), 747-762. http://dx.doi.org/10.1016/j.im.2003.08.011

Zeithalm, V. A. (1988). Consumer perceptions of price, quality and value: a means-end model and synthesis of evidence, Journal of Marketing, 52, 2-22. http://dx.doi.org/10.2307/1251446

\section{Notes}

Note 1. The Price of lodging was defined for a hotel having 3 stars based on a qualitative study between the analyzed set.

Note 2. The sample consists of $52.3 \%$ males and $47.7 \%$ females. 
APPENDIX 1. Situation 2, with Hotel website and always low prices (ALP)

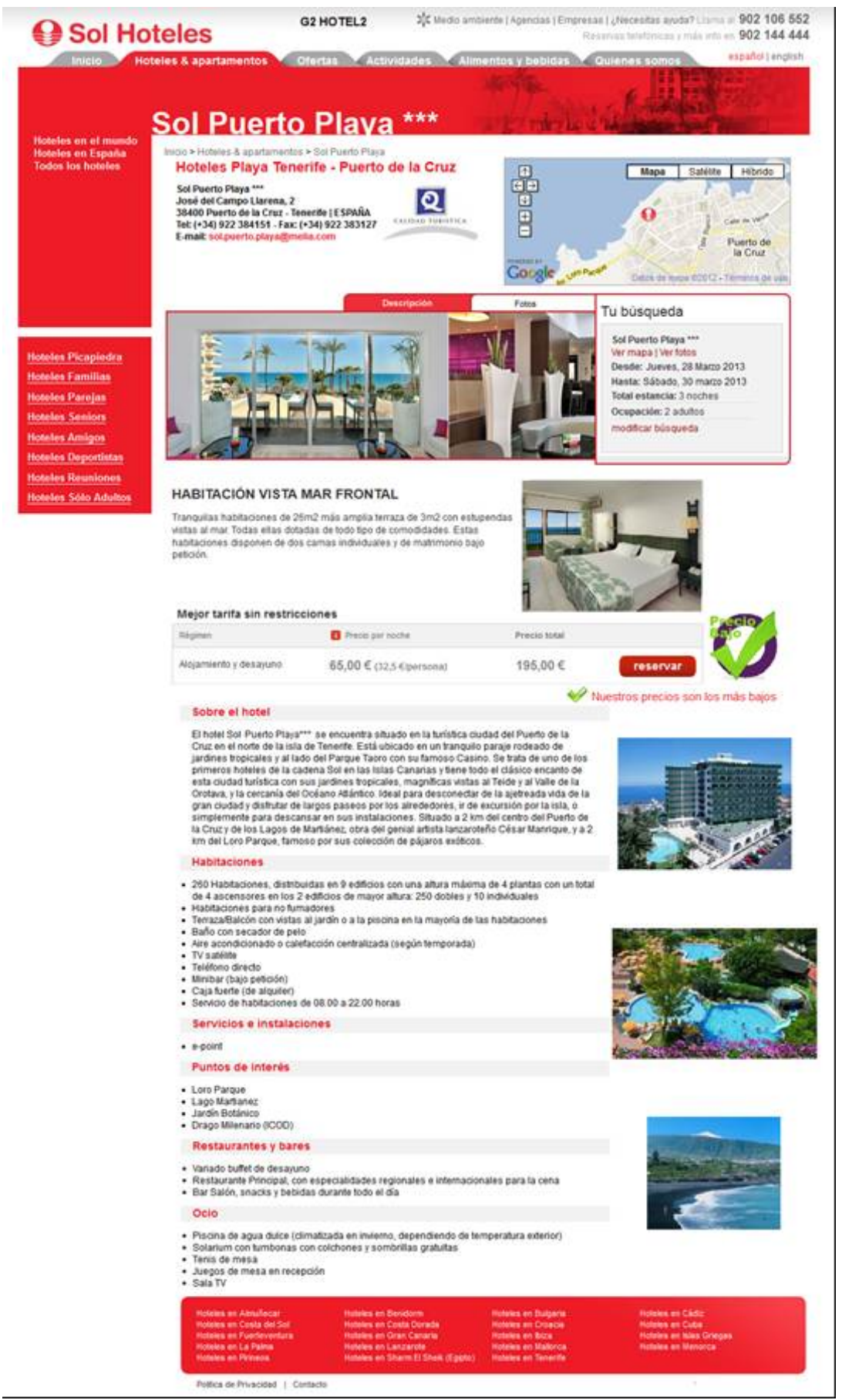


APPENDIX 2. Situation 8, with electronic retailer and Price beating guarantee (PB)

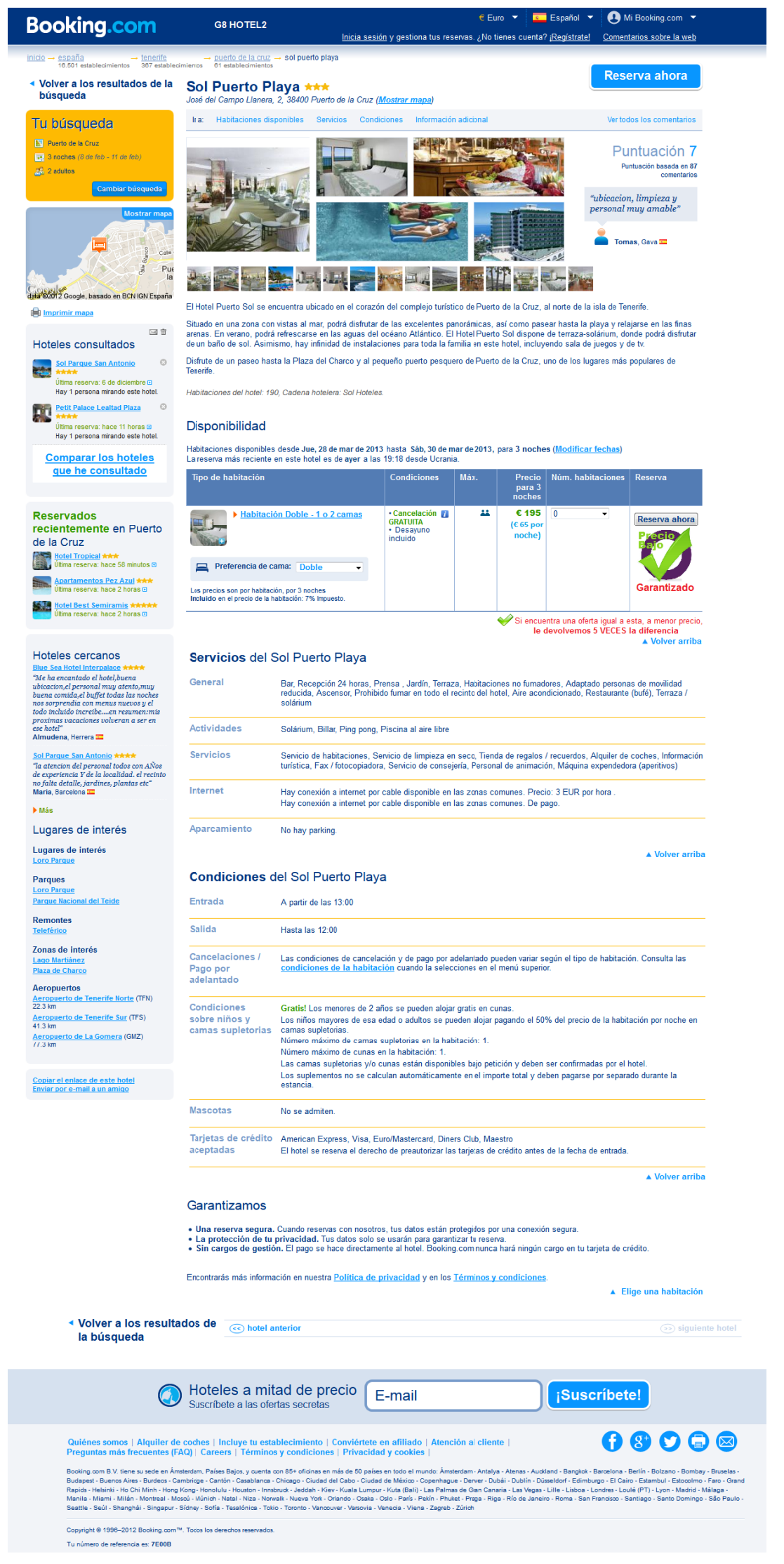

